\title{
Seroepidemiological aspects of Leishmania spp. in dogs in the Itaguai micro-region, Rio de Janeiro, Brazil
}

Aspectos soroepidemiológicos de Leishmania spp. em cães na microrregião de Itaguaí, Rio de Janeiro, Brasil

Claudia Bezerra da Silva ${ }^{1}$; Joice Aparecida Rezende Vilela ${ }^{1}$; Marcus Sandes Pires ${ }^{1}$; Huarrisson Azevedo Santos ${ }^{1}$; Aline Falqueto ${ }^{1}$; Maristela Peckle Peixoto ${ }^{1}$; Thais de Andrade Oliveira ${ }^{2}$; Fernanda Nunes Santos ${ }^{3}$; Valmir Laurentino Silva ${ }^{3}$; Argemiro Sanavria ${ }^{2}$; Carlos Luiz Massard ${ }^{1 *}$

\author{
${ }^{1}$ Laboratório de Hemoparasitos e Vetores da Estação para Pesquisas Parasitológicas W. O. Neitz, Departamento de Parasitologia Animal, \\ Instituto de Veterinária, Universidade Federal Rural do Rio de Janeiro - UFRRJ, Seropédica, RJ, Brasil \\ ${ }^{2}$ Laboratório de Doenças Parasitárias, Departamento de Epidemiologia e Saúde Pública, Instituto de Veterinária, \\ Universidade Federal Rural do Rio de Janeiro - UFRRJ, Seropédica, RJ, Brasil \\ ${ }^{3}$ Laboratório de Imunodiagnósticos, Departamento de Ciências Biológicas, Escola Nacional de Saúde Pública, \\ Fundação Oswaldo Cruz - FIOCRUZ, Rio de Janeiro, RJ, Brasil
}

Received April 4, 2012

Accepted September 21, 2012

\begin{abstract}
This study evaluated factors associated with the frequency of Leishmania spp. antibodies in dogs residing in the Itaguai micro-region, State of Rio de Janeiro, Brazil. Blood samples were collected from 524 dogs. The serum samples were submitted to indirect fluorescent antibody test (IFAT) and enzyme-linked immunosorbent assay (ELISA) for Leishmania spp. The frequency of seropositive dogs was $28.24 \%(\mathrm{n}=148)$ in the micro-region, and among the three municipalities within that region, the highest frequency $(\mathrm{p}<0.05)$ was observed in Seropedica $(59.46 \%)$, followed by Itaguai $(29.05 \%)$ and Mangaratiba (11.49\%). Regarding factors associated with the host, mongrel dogs and those over the age of two presented higher frequency of antibodies to Leishmania spp. $(\mathrm{p}<0.05)$. Concerning factors related to the environment and habits of the animal, dogs residing in rural areas ( $F R=1.67, \mathrm{p}=0.0002)$, living outside the residence $(F R=1.42, \mathrm{p}=0.0197)$, with access to forest, streams and pastures $(\mathrm{FR}=2.81, \mathrm{p}=0.0007)$, remaining loose $(\mathrm{FR}=1.66, \mathrm{p}=0.0073)$, and those that had no shelter $(\mathrm{FR}=2.16, \mathrm{p}<0.0001)$ were more likely to be seropositive. Canine leishmaniasis is a disease with high occurrence in the Itaguai micro-region, and aspects such as the definition of breed, age, habits and care by owners showed significant association in this micro-region.
\end{abstract}

Keywords: Leishmania spp., epidemiology, canine, enzyme-linked immunosorbent assay (ELISA), indirect fluorescent antibody test (IFAT).

\section{Resumo}

Este estudo avaliou os fatores associados à frequência de anticorpos específicos para Leishmania spp. em cáes domiciliados na microrregião de Itaguaí, Rio de Janeiro. Foram colhidas amostras de sangue de 524 cães. As amostras de soro foram submetidas a reação de imunofluorescência indireta (RIFI) e ensaio imunoenzimático indireto (ELISA-teste) para Leishmania spp. A frequência de cáes soropositivos foi de 28,24\% ( $\mathrm{n}=148)$ na microrregiáo e, entre os três municípios avaliados, a maior frequência $(\mathrm{p}<0,05)$ foi observada em Seropédica $(59,46 \%)$, seguida de Itaguaí $(29,05 \%)$ e Mangaratiba (11,49\%). Em relação aos fatores associados ao hospedeiro, observou-se que cáes sem raça definida e aqueles com idade acima de dois anos apresentaram maior frequência de anticorpos para Leishmania spp. $(\mathrm{p}<0,05)$. Em relação aos fatores relacionados ao ambiente e ao hábito do animal, os cães residentes em áreas rurais $(\mathrm{RF}=1,67, \mathrm{p}=0,0002)$, animais que vivem fora da residência $(\mathrm{RF}=1,42, \mathrm{p}=0,0197)$, com acesso à mata, córregos e pastagens $(F R=2,81, p=0,0007)$, que permanecem soltos $(R F=1,66, p=0,0073)$, e aqueles que não possuem abrigo $(\mathrm{RF}=2,16, \mathrm{p}<0,0001)$ apresentaram maior chance de serem soropositivos. A leishmaniose canina é uma enfermidade com elevada ocorrência na microrregião de Itaguai, e aspectos como definiçấo racial, idade, hábitos e cuidados estabelecidos pelo proprietário mostraram associação significativa nessa microrregião.

Palavras-chave: Leishmania spp., epidemiologia, canino, ensaio imunoenzimático indireto (ELISA), reação de imunofluorescência indireta (RIFI).

\footnotetext{
*Corresponding author: Carlos Luiz Massard

Departamento de Parasitologia Animal,

Universidade Federal Rural do Rio de Janeiro - UFRRJ,

Rod. BR 465, Km 7, CEP 23890-000, Seropédica, RJ, Brasil

e-mail: carlosmassard@ufrrj.br
} 


\section{Introduction}

Leishmaniasis, caused by the protozoa Leishmania spp., is a re-emerging anthropozoonosis considered to be a major public health problem. It is actually a set of diseases with important clinical significance and epidemiological diversity (BRASIL, 2007). In Brazil, the main species are classified as Leishmania (Leishmania) infantum $[=$ L. (L.) chagasi] and L. (Viannia) brasiliensis (REY, 2001). Considered a disease from the rural areas, leishmaniasis has undergone changes in its epidemiological profile, and cases are being recorded in urban areas (MONTEIRO et al., 2005; DANTAS-TORRES; BRANDÁO-FILHO, 2006), where dogs play an important role in maintaining the disease (BRASIL, 2007).

The occurrence of leishmaniasis is high in developing countries and social, economic and environmental aspects are determinants for its maintenance and propagation (LANGONI, 2004). Recommendations on environmental management and maintenance of peridomestic areas, keeping them clean and free of organic matter, have been made to reduce the incidence of leishmaniasis in areas of occurrence in humans (MARZOCHI et al., 2009).

Among the methods used to diagnose canine leishmaniasis, the Brazilian Ministry of Health recommends the use of enzyme-linked immunosorbent assay (ELISA) for initial screening of suspected dogs and indirect fluorescent antibody test (IFAT) for confirmation of positive cases (BRASIL, 2006). As described by Souza et al. (1982), serology tests can help in the diagnosis and are often used in epidemiological studies. Aguiar et al. (2010) also describe that the use of these two methods is interesting, because the ELISA allows simultaneous analysis of a large number of samples in a short time and IFAT can be used to confirm the specificity of positive samples, which is essential to an efficient diagnosis of leishmaniasis.

The importance of the canine reservoir comes from the frequent and close contact between dogs and humans (MARZOCHI et al., 2009). Although canine seroprevalence depends on ecological and social factors, as well as on the types of tests used, there is no consensus on the relationship between the occurrence in dogs and in humans (COSTA; VIEIRA, 2001). Risk factors associated with canine leishmaniasis have not been fully elucidated (BARBOZA et al., 2006). Some studies of the factors associated with canine leishmaniasis in Brazil have shown no association with gender, breed or age related to infection (GONTIJO; MELO, 2004). Thus, this study aimed to evaluate the frequency of seropositive dogs for Leishmania spp. in three municipalities comprised in the micro-region of Itaguai, State of Rio de Janeiro, and to evaluate the possible factors associated with the seropositivity of animals.

\section{Materials and Methods}

The study was carried out in the micro-region of Itaguai, located on the southern coastal part of the State of Rio de Janeiro, Brazil, between April 2010 and April 2011. This region covers an area of $907,007 \mathrm{~km}^{2}$ and comprises three municipalities: Itaguai, Seropedica and Mangaratiba. There are nearly 211,373 people living in this region, according to the Brazilian Institute of Geography and Statistics (IBGE, 2010).
To establish the minimum number of samples to be collected in the Itaguai micro-region, the equation described by Sampaio (2002) was used, considering confidence interval of 95\% and error margin of $4 \%$, and assuming expected prevalence of $19.6 \%$, based on the average of prevalence found in other studies carried out in the State of Rio de Janeiro (COUTINHO et al., 1985; CABRERA et al., 2003; SANTOS et al., 2005). Five hundred twenty-four (524) dogs were selected (Itaguai, $\mathrm{n}=166$; Seropedica, $\mathrm{n}=220$; Mangaratiba, $\mathrm{n}=138$ ) by non-probabilistic convenience sampling. From the 524 samples collected, 249 (47.5\%) were from rural areas and 275 (52.5\%) from urban areas.

A semi-structured questionnaire was applied to each dog owner to collect information regarding the animal (gender, age group, breed), handling by the owner (ectoparasiticide treatment; frequency of cleaning at environment with feces collection), place of residence (municipality; rural or urban area), habits (living inside the residence; local access; form that is created, presence of shelter), and possible clinical changes observed from clinical examination. Upon owners' consent, the animals were restrained for clinical examination and blood collection. A sample of $5 \mathrm{~mL}$ of peripheral blood was drawn from each animal through puncture of the cephalic vein and placed in labeled tubes with no anticoagulant. The tubes were then placed in a thermal container at nearly $4{ }^{\circ} \mathrm{C}$. Serum samples were obtained after centrifugation at $2500 \mathrm{xg}$ for 5 minutes, and stored at $-20^{\circ} \mathrm{C}$ until performance of serological assays.

The following methods were used to test for antibodies against Leishmania spp.: indirect fluorescent antibody test (IFAT) and enzyme-linked immunosorbent assay (ELISA) (Bio-Manguinhos/Fiocruz, Rio de Janeiro, Brazil). The serological reactions were performed according to the manufacturer's instructions. The antigens used were Leishmania major-like for ELISA and Leishmania infantum for IFAT. Animals were considered reactive to Leishmania spp. when tested positive both at ELISA and IFAT at 1:40 dilution.

The frequency data were compared in the different categories observing the Chi square $\left(X^{2}\right)$ and Fisher's exact tests at $5 \%$ level of significance. The frequency ratio (FR) $(\mathrm{p}<0.05)$ was estimated for the factors associated with positivity to Leishmania spp. All statistical analyses were carried out using Bioestat -4.0 software program (AYRES, 2000).

These procedures were approved by the Ethics Committee on Research of the Federal Rural University of Rio de Janeiro - UFRRJ (COMEP/UFRRJ), protocol number 124/2011, process number 23083.005908/2011-01.

\section{Results}

The frequency of dogs that tested seropositive for Leishmania spp. in the micro-region of Itaguai was $28.24 \%(n=148 / 524)$. Seropositivity showed significant association $(\mathrm{p}<0.05)$ in relation to the municipality of origin. The highest frequency of seropositive dogs was observed in Seropedica (59.46\%, $\mathrm{n}=88 / 148)$, followed by Itaguai $(29.05 \%, \mathrm{n}=43 / 148)$ and Mangaratiba $(11.49 \%$, $\mathrm{n}=17 / 148)$ (Table 1$)$ 
Moreover, dogs living in rural areas presented higher frequency of seropositivity than dogs residing in urban areas $(\mathrm{p}<0.05)$. However, the gender of the animals did not affect the predisposition for leishmaniasis $(p>0.05)$. Thus, dogs in the urban area of Seropedica $(F R=3.25, \mathrm{p}<0.0001)$, as well as those from the rural area of that municipality $(\mathrm{FR}=1.67, \mathrm{p}=0.0002)$ were more likely to become infected with Leishmania spp. than animals from the other two municipalities.

Regarding the possible intrinsic factors of dogs associated with seropositivity, there was only one association $(\mathrm{p}<0.05)$, between breed and age. Dogs from two to five years old $(F R=1.47$, $\mathrm{p}=0.0174)$ and mongrels $(\mathrm{FR}=1.70, \mathrm{p}=0.014)$ showed higher frequency of seropositivity for Leishmania spp. From the seropositive mongrel animals $(32.24 \%, \mathrm{n}=118 / 366), 65.25 \%(\mathrm{n}=77 / 118)$ belonged to rural areas, while only $34.75 \%(n=41 / 118)$ were found in urban spaces.

With respect to the management adopted by the owner and its association with seropositivity, the variables: treatment against ectoparasite infestation and lack of cleaning daily with feces collection at environment where the dog often remains, were

Table 1. Frequency of dogs seropositive for Leishmania spp. depending on living environment, factors inherent to the dog (gender, age, breed definition), management adopted by owner (ectoparasiticide treatment, removal of feces), and habits of the animal, between April 2010 and April 2011, observed during the study in the Itaguai micro-region, RJ, Brazil.

\begin{tabular}{|c|c|c|c|c|c|c|}
\hline \multirow[t]{2}{*}{ Factors } & \multirow[t]{2}{*}{$\mathbf{N}$} & \multicolumn{2}{|c|}{$\begin{array}{l}\text { Seropositive for } \\
\text { Leishmania spp. }\end{array}$} & \multirow[t]{2}{*}{ FR } & \multirow[t]{2}{*}{$95 \% \mathrm{CI}$} & \multirow[t]{2}{*}{ p-value } \\
\hline & & $\mathbf{n}$ & $\%$ & & & \\
\hline \multicolumn{7}{|l|}{ Municipality of the micro-region } \\
\hline Seropedica & 220 & $88^{\mathrm{a}}$ & 40.00 & 3.25 & 2.02 to 5.21 & $<0.0001$ \\
\hline Itaguai & 166 & $43^{\mathrm{b}}$ & 25.90 & 2.10 & 1.26 to 3.52 & 0.0024 \\
\hline Mangaratiba & 138 & $17^{\mathrm{c}}$ & 12.32 & 1 & - & - \\
\hline \multicolumn{7}{|l|}{ Living environment } \\
\hline Rural & 249 & $89^{a}$ & 35.74 & 1.67 & 1.26 to 2.21 & 0.0002 \\
\hline Urban & 275 & $59^{\mathrm{b}}$ & 21.45 & 1 & - & - \\
\hline \multicolumn{7}{|l|}{ Gender } \\
\hline Male & 280 & $76^{a}$ & 27.14 & 1 & - & - \\
\hline Female & 244 & $72^{\mathrm{a}}$ & 29.51 & 1.09 & 0.83 to 1.43 & 0.3076 \\
\hline \multicolumn{7}{|l|}{ Age group } \\
\hline$<6$ months to $<2$ years & 171 & $41^{\mathrm{b}}$ & 23.98 & 1 & - & - \\
\hline$\geq 2$ years to $<5$ years & 153 & $54^{a}$ & 35.29 & 1.47 & 1.05 to 2.07 & 0.0174 \\
\hline$\geq 5$ years & 200 & $53^{\mathrm{ab}}$ & 26.50 & 1.11 & 0.78 to 1.57 & 0.3309 \\
\hline \multicolumn{7}{|l|}{ Breed definition } \\
\hline Mongrel & 366 & $118^{\mathrm{a}}$ & 32.24 & 1.70 & 1.19 to 2.42 & 0.014 \\
\hline Defined breed & 158 & $30^{\mathrm{b}}$ & 18.99 & 1 & - & - \\
\hline \multicolumn{7}{|l|}{ Ectoparasiticide treatment } \\
\hline Yes & 389 & $90^{\mathrm{b}}$ & 23.14 & 1 & - & - \\
\hline No & 135 & $58^{\mathrm{a}}$ & 42.96 & 1.86 & 1.42 to 2.42 & $<0.0001$ \\
\hline \multicolumn{7}{|l|}{ Removal of feces } \\
\hline Yes & 374 & $82^{\mathrm{b}}$ & 21.93 & 1 & - & - \\
\hline No & 150 & $66^{\mathrm{a}}$ & 44.00 & 2.01 & 1.54 to 2.61 & $<0.0001$ \\
\hline \multicolumn{7}{|l|}{ Animal lives inside residence } \\
\hline No & 363 & $113^{a}$ & 31.13 & 1.42 & 1.02 to 1.98 & 0.0197 \\
\hline Yes & 161 & $35^{\mathrm{b}}$ & 21.88 & 1 & - & - \\
\hline \multicolumn{7}{|l|}{ Places of access } \\
\hline Urban Environment & 193 & $40^{\mathrm{b}}$ & 20.73 & 1.60 & 0.76 to 3.37 & 0.1382 \\
\hline Forest, streams and pastures & 277 & $101^{\mathrm{a}}$ & 36.46 & 2.81 & 1.39 to 5.71 & 0.0007 \\
\hline Yard/confined area & 54 & $7^{\mathrm{b}}$ & 12.96 & 1 & - & - \\
\hline \multicolumn{7}{|l|}{ Habits } \\
\hline Loose & 372 & $116^{\mathrm{a}}$ & 31.18 & 1.66 & 1.10 to 2.52 & 0.0073 \\
\hline Confined by day/loose at the night & 40 & $11^{\mathrm{ab}}$ & 27.50 & 1.47 & 0.78 to 2.76 & 0.1738 \\
\hline Always confined & 112 & $21^{\mathrm{b}}$ & 18.75 & 1 & - & - \\
\hline \multicolumn{7}{|l|}{ Provided with shelter } \\
\hline Yes & 358 & $74^{\mathrm{b}}$ & 20.67 & 1 & - & - \\
\hline No & 166 & $74^{a}$ & 44.58 & 2.16 & 1.66 to 2.81 & $<0.0001$ \\
\hline
\end{tabular}

N: number of animals examined by serologic tests; n: number of seropositive animals; FR: Frequency Ratio; CI: confidence interval. ${ }^{a}$ Means followed by the same letter do not differ by Chi-square or Fisher's exact tests $(p>0.05)$. 
significant $(\mathrm{p}<0.05)$ (Table 1$)$. Dogs that did not receive treatment against ectoparasites $(F R=1.86, \mathrm{p}<0.0001)$ and dwelled in a place where feces were not routinely collected $(F R=2.01, p<0.0001)$ showed higher frequency of antibodies to Leishmania spp. than the others (Table 1).

Concerning the animals' habits, there was a significant association $(\mathrm{p}<0.05)$ of all variables with seropositivity for Leishmania spp. Animals living outside the home (FR = 1.42, $\mathrm{p}=0.0197)$, those with access to forests, streams and pastures $(\mathrm{FR}=2.81, \mathrm{p}=0.0007)$, those allowed to roam free $(\mathrm{FR}=1.66$, $\mathrm{p}=0.0073)$, and those with no shelter $(\mathrm{FR}=2.16, \mathrm{p}<0.0001)$ were more likely to be seropositive for Leishmania spp. (Table 1).

The following clinical findings were observed in the animals during this research: lymphadenopathy, onychogryphosis and skin diseases (dry desquamation, hyperkeratosis, eczema, oily seborrhea, alopecia, mucosal ulcerations and lesions in the pinna). These variables were not significantly associated $(p>0.05)$ to seropositivity, except for skin diseases $(\mathrm{p}<0.05)$. Few animals presented lymphadenopathy $(\mathrm{n}=16)$ and onychogryphosis $(\mathrm{n}=10)$.

\section{Discussion}

The serologic evidence observed in this study demonstrated the participation of dogs as potential reservoirs for this parasite in the domestic environment, mainly in areas of occurrence of leishmaniasis in humans - typical of the region studied. These findings corroborate other epidemiological studies on this etiologic agent (OLIVEIRA et al., 2010; ALMEIDA et al., 2009).

Among the three municipalities where the animals lived, the highest seropositivity was found in Seropedica, followed by Itaguai and Mangaratiba. In a study performed by Cardoso et al. (2009) in Seropedica, species of sandflies vectors of cutaneous leishmaniasis were captured, suggesting that these species are potential vectors of leishmaniasis in the municipality and that dogs should be considered potential reservoirs of this parasite due to the high frequency of seropositivity detected. Souza et al. (2009) and Aguiar et al. (1996), analyzing sandflies in the green coast of the State of Rio de Janeiro, found some species of great epidemiological importance. In addition, human migrations to this area, with the construction of a new petrochemical and port complex, have increased the prevalence of leishmaniasis in the region (AGUIAR et al., 1996). Dogs seropositive to Leishmania spp. have been detected in some other studies conducted in coastal areas of the State of Rio de Janeiro (CABRERA et al., 2003; MADEIRA et al., 2006), as found in Mangaratiba in this study.

Marzochi et al. (2009) showed that the seroprevalence of canine leishmaniasis in endemic areas in the State of Rio de Janeiro had decreased considerably over time. However, the frequency of dogs seropositive to Leishmania spp. in this study was higher when compared to other studies (UCHÔA et al., 2001; SANTOS et al., 2005; CARDOSO, 2007). The results of the present study showed that environmental aspects, such as the presence of native forest, are propitious environments for the development of leishmaniasis vectors. Moreover, several areas are still predominantly rural despite the urban expansion in the region. This fact is closely related to the low socioeconomic status of the local population, which contributes to the poor sanitary conditions in the areas surrounding homes, thus favoring the development of microenvironments favorable to the reproduction of insect vectors.

Regarding variables associated with the seropositivity of animals, the gender of dogs presented no association, as also found in other studies (CABRERA et al., 2003; ALMEIDA et al., 2009; OLIVEIRA et al. 2010; FRANÇA-SILVA et al., 2003; MATOS et al., 2006).

Regarding age, Matos et al. (2006), Feitosa et al. (2000) and França-Silva et al. (2003) observed that the animals most affected were young adults, which corroborates the findings of the present study. This may be related to an inherent feature of the management adopted by the pet owner, because dogs are kept more often outside the home in this age group, increasing the chance of contact with the vectors (MATOS et al., 2006). Although dogs aged two to five years old were more affected in the present study, dogs over five years old showed no difference compared to younger animals. Furthermore, this observation may be related to the management adopted by the owners of both groups of animals, which require more care because of their age, remaining longer inside the home, therefore, with less contact with vectors.

This study showed that rural areas have greater propensity for mongrels that remain loose in the vicinity and without proper management. Many times, mongrel dogs are removed from the streets and, despite receiving shelter and food, remain without proper care by the owner due to economic reasons, unlike some dogs with defined breed in urban areas. According to Oliveira et al. (2010) and Almeida et al. (2010), the breed of dogs is not an associated factor to infection by Leishmania, but most of the animals reactive to Leishmania spp. were crossbreds, consistent with the findings of this study.

During this study, it was also observed that some animals that received no treatment for ectoparasites were reactive in the serological tests. Some studies demonstrated the involvement of chemicals in the control of leishmaniasis, as reported by Teodoro et al. (1999), where pyrethroid-based insecticides were used in the reduction of sandflies in endemic areas. The owners interviewed in the present study used pyrethroids against ectoparasites on their dogs, through bathing and spraying it on the environment. Nevertheless, it was observed that most animals that were treated with ectoparasiticide belonged to urban areas that concentrate animals that live under better conditions, in a restricted environment, receiving appropriate sanitary-hygienic care, because of the better financial conditions of their owners. While sandflies are recognized as major transmitters of leishmaniasis, some studies discussed the participation of ectoparasites, such as fleas and ticks, in the disease cycle (COUTINHO et al., 2005; PAZ et al., 2010) because of the high frequency and quantity that these arthropods afflict dogs. However, there is no consensus on the transmission of Leishmania by others ectoparasites, as well as on the use of ectoparasiticides contributing to decrease this disease.

Regarding the collection of animal feces, there is a satisfactory amount of seropositive dogs in this micro-region, which live in yards or other areas that are not periodically cleaned. In relation to this aspect, Reis et al. (2011) pointed out that the presence of organic waste such as sewage and garbage influenced the epidemiology of leishmaniasis, since the vectors of this disease develop in organic 
matter and moist environments. In homes from the Itaguai micro-region, where owners routinely remove feces from yards or surrounding areas, dogs are usually allowed to roam, with free access to areas where they tend to do their physiological needs. This facilitates the contact with vectors, attracted by decaying organic matter in the vicinity where the animals roam.

In this study, a direct association between animals and seropositivity was observed in rural areas. In these areas, dogs are let loose, moving beyond the household surroundings and, because of this mobility, they may be more exposed to factors that increase the likelihood of infection by Leishmania spp.; as also observed by Santos et al. (2005) and Oliveira et al. (2010) in their studies. According to Oliveira et al. (2010), the variation in prevalence between rural and urban areas is intrinsically linked to domestic and peridomestic environmental conditions for the development of infection, which may include the vector, canine population, changes caused by human presence, accumulation of garbage and other organic matter, and poor sanitation (CAMARGO-NEVES et al., 2003). In addition, rural areas have greater diversity of animals than urban ones, whether domestic or wild, as well as the presence of riparian forests or forest fragments, which are predisposing factors for the presence of sandflies.

Dye et al. (1992) demonstrated that animals that stay outdoors are potentially more exposed to infected insects, as well as depicted by Frehse et al. (2010) to detect animals that lived outside home like dog guard. This was also observed in the present study, once the dogs routinely kept inside the home were less seropositive. Dogs that had frequent contact with forests, streams and pastures were more seropositive in relation to the other categories analyzed. According to Santos et al. (2005), the presence of abundant vegetation, high humidity and the presence of other domestic and synanthropic animals provide excellent conditions for the presence of sandflies, which disseminate the etiologic agents of this disease. In a study by Almeida et al. (2010), the authors observed that some of the seropositive animals had access to remaining forests and streams, rivers or reservoirs. When assessing confinement conditions, Oliveira et al. (2010) observed that animals with free access to multiple sites, unlike those limited to the house and/or backyard, presented higher seroprevalence.

Likewise, in the present study, dogs that were always allowed to roam freely presented the highest frequency of seropositivity, with a statistically significant difference in relation to the animals in other categories. Epidemiologically, it is known that canine leishmaniasis is a disease of local nature and that the risk factors can vary from one region to another. However, it seems quite clear that the lifestyle of each particular dog can favor exposure to vectors (SANTOS et al., 2010). In this study, the animals that did not have shelter were more seroreactive to Leishmania spp., which corroborates the findings by Gálvez et al. (2010).

Many studies have evaluated the clinical signs of animals infected by Leishmania spp. (OLIVEIRA et al., 2010; ALMEIDA et al., 2009, 2010; MATOS et al., 2006). In this research, some clinical changes were observed in relation to the disease, such as lymphadenopathy, onychogryphosis and skin changes. Only skin diseases were associated with seropositivity in the dogs studied. Santos et al. (2005) and Almeida et al. (2009) reported that the presence of skin lesions is associated with positive results in immune reactions; the same was observed in this study. Our findings corroborate those of other studies (FEITOSA et al., 2000; GÁLLEGO, 2004), according to which skin changes are the most commonly observed clinical signs in canine leishmaniasis.

\section{Conclusions}

Canine leishmaniasis is a disease with high occurrence in the rural areas of the Itaguai micro-region, affecting mainly dogs with no defined breed, aged from two to five years old, roaming freely with access to forests and streams. In this study, it was possible to identify that the control of ectoparasites, presence of shelter, and clean conditions of the environment where the dog spends most of the time are aspects that reduce the likelihood of infection by the parasites of Leishmania genus in dogs and, therefore, can be used as preventive measures.

\section{Acknowledgments}

The authors are grateful to the National Council for Scientific and Technological Development - CNPq and 'Carlos Chagas Filho' Foundation for Research Support of the State of Rio de Janeiro - FAPERJ for their financial support.

\section{References}

Aguiar GM, Medeiros WM, Marco TS, Santos SC, Gambardella S. Ecologia dos flebotomíneos da Serra do Mar, Itaguaí, estado do Rio de Janeiro, Brasil. I - A fauna flebotomínica e prevalência pelo local e tipo de captura (Diptera, Psychodidae, Phlebotominae). Cad Saúde Públ 1996; 12(2): 195-206. PMid:10904321. http://dx.doi.org/10.1590/ S0102-311X1996000200008

Aguiar DM, Oliveira TMFS, Cavalcante GT, Labruna MB, Camargo LMA, Machado RZ, et al. Seroprevalence of anti-Leishmania spp. antibodies in rural dogs from the city of Monte Negro, State of Rondônia, Brazil. Rev Bras Parasitol Vet 2010; 19(1): 71-72. PMid:20385065. http:// dx.doi.org/10.4322/rbpv.01901014

Almeida ABPF, Faria RP, Pimentel MFA, Dahroug MAA, Turbino NCMR, Sousa VRF. Inquérito soroepidemiológico de leishmaniose canina em áreas endêmicas de Cuiabá, estado de Mato Grosso. Rev Soc Bras Med Trop 2009; 42(2): 156-159. http://dx.doi.org/10.1590/S003786822009000200012

Almeida ABPF, Mendonça AJ, Sousa VRF. Prevalência e epidemiologia da leishmaniose visceral em cães e humanos, na cidade de Cuiabá, Mato Grosso, Brasil. Ciênc Rural 2010; 40(7): 1610-1615. http://dx.doi. org/10.1590/S0103-84782010005000102

Ayres M. BioEstat 2.0 - Aplicaçôes estatísticas nas áreas das ciências biológicas e médicas. Tefé: Sociedade Civil Mamirauá; 2000.

Barboza DCPM, Gomes Neto CMB, Leal DC, Bittencourt DVV, Carneiro AJB, Souza BMPS, et al. Estudo de coorte em áreas de risco para leishmaniose visceral canina, em municípios da regiáo metropolitana de Salvador, Bahia, Brasil. Rev Bras Saúde Prod An 2006; 7(2): 152-163.

Brasil. Ministério da Saúde. Manual de vigilância e controle da leishmaniose visceral. Brasília: Ministério da Saúde; 2006. 
Brasil. Ministério da Saúde. Manual de vigilância da leishmaniose tegumentar americana. 2nd ed. Brasília: Ministério da Saúde; 2007.

Cabrera MAA, Paula AA, Camacho LAB, Marzochi MCA, Xavier SC, Silva AVM, et al. Canine visceral leishmaniasis in Barra de Guaratiba, Rio de Janeiro, Brazil: assessment of risk factors. Rev Inst Med Trop S Paulo 2003; 45(2): 79-83. PMid:12754572. http://dx.doi.org/10.1590/ S0036-46652003000200005

Camargo-Neves VLF, Spínola R, Lage L. A leishmaniose visceral americana no estado de São Paulo: situação spidemiológica em 20012002. Rev Soc Bras Med Trop 2003; 36(S2): 27-29. PMid:15719771. http://dx.doi.org/10.1590/S0037-86822003000700009

Cardoso PG. Levantamento da fauna flebotominica e ocorrência de cães sororreagentes para leishmaniose tegumentar americana no municipio de Seropédica, estado do Rio de Janeiro [Tese]. Rio de Janeiro: Universidade Federal Rural do Rio de Janeiro; 2007.

Cardoso PG, Souza MB, Sanavria A, Meira AM, Meródio JC. Flebótomos de áreas com ocorrências de casos humanos de leishmaniose tegumentar americana no município de Seropédica, estado do Rio de Janeiro. Rev Soc Bras Med Trop 2009; 42(2): 146-150. PMid:19448931. http://dx.doi. org/10.1590/S0037-86822009000200010

Costa CHN, Vieira JBF. Mudanças no controle da leishmaniose visceral no Brasil. Rev Soc Bras Med Trop 2001; 34(2): 223-28. PMid:11391448. http://dx.doi.org/10.1590/S0037-86822001000200013

Coutinho SG, Nunes MP, Marzochi MCA, Tramontano N. A survey for american cutaneous and visceral leishmaniasis among 1,342 dogs from areas in Rio de Janeiro (Brazil) where the human diseases occur. Mem Inst Oswaldo Cruz 1985; 80(1): 17-22. PMid:3910994. http://dx.doi. org/10.1590/S0074-02761985000100003

Coutinho MTZ, Bueno LL, Sterzik A, Fujiwara RT, Botelho JR, De Maria M, et al. Participation of Rhipicephalus sanguineus (Acari: Ixodidae) in the epidemiology of canine visceral leishmaniasis. Vet Parasitol 2005; 128(1-2): 149-155. PMid:15725545. http://dx.doi. org/10.1016/j.vetpar.2004.11.011

Dantas-Torres F, Brandão-Filho SP. Expansão geográfica da leishmaniose visceral no estado de Pernambuco. Rev Soc Bras Med Trop 2006; 39(4):352-356. PMid:17119750. http://dx.doi.org/10.1590/ S0037-86822006000400007

Dye C, Killick-Kendrick R, Vitutia MM, Walton R, KillickKendrick M, Harith AE, et al. Epidemiology of canine leishmaniasis: prevalence, incidence and basic reproduction number calculated from a cross-sectional serological survey on the island of Gozo, Malta. Parasitology 1992; 105(1): 35-41. PMid:1437274. http://dx.doi. org/10.1017/S0031182000073662

Feitosa MM, Ikeda FA, Luvizotto MCR, Perri SHV. Aspectos clínicos de cães com leishmaniose visceral no município de Araçatuba, São Paulo (Brasil). Clin Vet 2000; 5(28): 36-44.

França-Silva JC, Da Costa RT, Siqueira AM, Machado-Coelho GL, Da Costa CA, Mayrink W, et al. Epidemiology of canine visceral leishmaniosis in the endemic area of Montes Claros municipality, Minas Gerais state, Brazil. Vet Parasitol 2003; 111(2-3): 161-173. http://dx.doi. org/10.1016/S0304-4017(02)00351-5

Frehse MS, Greca Júnior H, Ullmann LS, Camossi LG, Machado JG, Langoni $\mathrm{H}$, et al. Surveillance of canine visceral leishmaniasis in a diseasefree area. Rev Bras Parasitol Vet 2010; 19(1): 62-64. PMid:20385062. http://dx.doi.org/10.4322/rbpv.01901011
Gállego M. Zoonosis emergentes por patógenos parasitos: las leishmaniosis. Rev Sci Tech Off Int Epiz 2004; 23(2): 661-676.

Gálvez R, Miró G, Descalzo MA, Nieto J, Dado D, Martín O, et al. Emerging trends in the seroprevalence of canine leishmaniosis in the Madrid region (central Spain). Vet Parasitol 2010; 169(3-4): 327-334. PMid:20031330. http://dx.doi.org/10.1016/j.vetpar.2009.11.025

Gontijo CMF, Melo NM. Leishmaniose visceral no Brasil: quadro atual, desafios e perspectivas. Rev Bras Epidemiol 2004; 7(3): 338-349. http:// dx.doi.org/10.1590/S1415-790X2004000300011

Instituto Brasileiro de Geografia e Estatística - IBGE. 2010. [online]. [cited 2012 Jan 02]. Available from: http://www.ibge.gov.br/home/ estatistica/populacao/censo2010/resultados_dou/RJ2010.pdf.

Langoni H. Zoonoses and human beings. J Venom Anim Toxins Incl Trop Dis 2004; 10(2): 111-111. http://dx.doi.org/10.1590/S167891992004000200001

Madeira MF, Schubach AO, Schubach TMP, Pereira SA, Figueiredo FB, Baptista C, et al. Post mortem parasitological evaluation of dogs seroreactive for Leishmania from Rio de Janeiro, Brazil. Vet Parasitol 2006; 138(3-4): 366-370. PMid:16520002. http://dx.doi. org/10.1016/j.vetpar.2006.01.059

Marzochi MCA, Fagundes A, Andrade MV, Souza MB, Madeira MF, Mouta-Confort E, et al. Visceral leishmaniasis in Rio de Janeiro, Brazil: eco-epidemiological aspects and control. Rev Soc Bras Med Trop 2009; 42(5): 570-580. PMid:19967242. http://dx.doi.org/10.1590/ S0037-86822009000500017

Matos MM, Filgueira KD, Amora SSA, Suassuna ACD, Ahid SMM, Alves ND. Ocorrência da leishmaniose visceral em cães em Mossoró, Rio Grande do Norte. Ciênc Animal 2006; 16(1): 51-54.

Monteiro EM, Silva JCF, Costa RT, Costa DC, Barata RA, Paula EV, et al. Leishmaniose visceral: estudo de flebotomíneos e infecção canina em Montes Claros, Minas Gerais. Rev Soc Bras Med Trop 2005; 38(2): 147-152. PMid:15821789. http://dx.doi.org/10.1590/ S0037-86822005000200004

Oliveira LCP, Araújo RR, Alves CR, Mouta-Confort E, López JA, Lima FWM. Seroprevalence and risk factors for canine visceral leishmaniasis in the endemic area of Dias D'Ávila, state of Bahia, Brazil. Rev Soc Bras Med Trop 2010; 43(4): 400-404. PMid:20802939. http://dx.doi.org/10.1590/ S0037-86822010000400013

Paz GF, Ribeiro MFB, Magalhães DF, Sathler KPB, Morais MHF, Fiúza VOP, et al. Association between the prevalence of infestation by Rhipicephalus sanguineus and Ctenocephalides felis felis and the presence of anti-Leishmania antibodies: A case-control study in dogs from a Brazilian endemic area. Prev Vet Med 2010; 97(2): 131-133. PMid:20869131. http://dx.doi.org/10.1016/j.prevetmed.2010.08.006

Reis HR, Lopes-Mori FMR, Reis CR, Freire RL, Marana ERM, Chryssafidis AL, et al. Soroprevalência da leishmaniose tegumentar americana (LTA) canina e fauna de flebotomíneos (Diptera: Psychodidae) em Bela Vista do Paraíso, Paraná. Semina: Ciênc Agrárias 2011; 32(3): 1083-1094. http://dx.doi.org/10.5433/1679-0359.2011v32n3p1083

Rey L. Leishmania e leishmaníases: Os parasitos. In: Rey L. Parasitologia. 3rd ed. Rio de Janeiro: Guanabara Koogan; 2001. p. 214 239.

Sampaio IBM. Estatística aplicada à experimentação animal. 2nd ed. Belo Horizonte: FEPMVZ; 2002.

Santos GPL, Sanavria A, Marzochi MCA, Santos EGB, Silva VL, Pacheco RS, et al. Prevalência da infecção canina em áreas endêmicas de 
leishmaniose tegumentar americana, do município de Paracambi, estado do Rio de Janeiro, no período entre 1992 e 1993. Rev Soc Bras Med Trop 2005; 38(2): 161-166. PMid:15821792. http://dx.doi.org/10.1590/ S0037-86822005000200007

Santos JML, Dantas-Torres F, Mattos MRF, Lino FRL, Andrade LSS, Souza RCA, et al. Prevalência de anticorpos antileishmania spp em cães de Garanhuns, Agreste de Pernambuco. Rev Soc Bras Med Trop 2010; 43(1): 41-45. PMid:20305967. http://dx.doi.org/10.1590/ S0037-86822010000100010

Souza MB, Carvalho RW, Machado RNM, Wermelinger ED. Flebotomíneos de áreas com notificaçóes de casos autóctones de leishmaniose visceral canina e leishmaniose tegumentar americana em Angra dos Reis, Rio de Janeiro, Brasil. Rev Bras Entomol 2009; 53(1): $147-$ 150. http://dx.doi.org/10.1590/S0085-56262009000100031
Souza WJS, Coutinho SG, Marzochi MCA, Toledo LM, Gottlieb MV. Utilização da reação de imunofluorescência indireta no acompanhamento da terapêutica da leishmaniose tegumentar americana. Mem Inst Oswaldo Cruz 1982; 77(3): 247-253. PMid:6763131. http://dx.doi.org/10.1590/ S0074-02761982000300003

Teodoro U, Kühl JB, Santos DR, Santos ES. Impacto de alterações ambientais na ecologia de flebotomíneos no sul do Brasil. Cad Saúde Públ 1999; 15(4): 901-906. PMid:10633213. http://dx.doi.org/10.1590/ S0102-311X1999000400025

Uchôa CMA, Serra CMB, Duarte R, Magalhães CM, Silva RM, Theophilo F, et al. Aspectos sorológicos e epidemiológicos da leishmaniose tegumentar americana canina em Maricá, Rio de Janeiro, Brasil. Rev Soc Bras Med Trop 2001; 34(6): 563-568. http://dx.doi.org/10.1590/ S0037-86822001000600011 